\title{
Of mosquitoes and men: mitigating Zika risk via Men's family planning and male contraception
}

\author{
Brian T. Nguyen * (1) and Robyn Schickler
}

\begin{abstract}
Background: Outbreaks of mosquito-borne viral illnesses commonly occur after storms. As storms are predicted to worsen in intensity and frequency, mosquito-borne viruses, including the Zika virus are expected to spread, and with devastating consequences. While the disease is self-limited, pregnant women who contract Zika can transmit the virus to their fetuses, causing neurodevelopmental abnormalities, including microcephaly. An overlooked vector of the Zika virus, however, is men whose semen can transmit the virus at the time of sexual intercourse. Current recommendations for preventing the sexual transmission of Zika are inadequate and need to emphasize male reproductive responsibility, via expanding services for men's family planning and developing novel male contraceptives.

Main body: To prevent the sexual transmission of Zika, the World Health Organization recommends that couples use condoms or abstain from sexual activity for at least 6 months when traveling in Zika-infected areas. Strict adherence to these recommendations is neither practical nor adequate to address Zika's sexual transmission. As up to 13\% of couples who use condoms experience unintended pregnancy, semen and consequent viral exposure is imminent. The use of contraception beyond just barrier methods is essential. However, the burden of contraception largely falls upon women and efforts to prevent vertical transmission are often aimed at educating women, when the outcome is equally undesirable among their male partners. These short-comings highlight the lack of attention to men's options for family planning. Educating men about the full range of contraceptive options, correcting misconceptions about the efficacy of withdrawal and barrier contraceptive methods, increasing access to vasectomy, and developing novel male contraceptive options would allow shared responsibility for the prevention of unintended pregnancy and Zika-related morbidity.
\end{abstract}

Conclusion: Gaps in recommendations to prevent the sexual transmission of Zika provide an opportunity to develop men's family planning initiatives and the range of accessible contraceptives to men.

Keywords: Male partner, Male contraception, men's reproductive health, Zika, Family planning

\section{Background}

In 2017, the United States (US) confirmed its first cases of Zika infection in Texas and Florida, with 4 cases acquired through sexual transmission [1]. That same year, the US also fell victim to a record-breaking hurricane season [2]. As the National Oceanic and Atmospheric Administration projects that climate change will increase both the intensity and frequency of hurricanes along the Atlantic coast through the twenty-first century [3], and as populations continue to grow in urban, coastal areas

\footnotetext{
* Correspondence: Brian.trung.nguyen@gmail.com

Section of Family Planning, Department of Obstetrics and Gynecology, Keck School of Medicine of the University of Southern California, Los Angeles, CA, USA
}

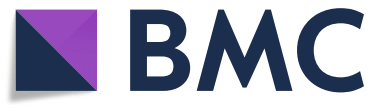

(c) The Author(s). 2018 Open Access This article is distributed under the terms of the Creative Commons Attribution 4.0 International License (http://creativecommons.org/licenses/by/4.0/), which permits unrestricted use, distribution, and reproduction in any medium, provided you give appropriate credit to the original author(s) and the source, provide a link to the Creative Commons license, and indicate if changes were made. The Creative Commons Public Domain Dedication waiver (http://creativecommons.org/publicdomain/zero/1.0/) applies to the data made available in this article, unless otherwise stated.

[4], these circumstances will contribute to a public health "perfect storm." Storms and their receding waters, particularly in regions that lack the resources and infrastructure for clean-up and vector control, leave stagnant pools that become breeding grounds for mosquitos that thrive and cause mosquito-borne viral infections [5], such as West Nile or Zika. After Hurricane Katrina (August 29, 2005), the incidence of West Nile Virus in storm-damaged regions more than doubled within 3 weeks [6]. While previous experience with disease outbreaks after hurricanes has spurred post-disaster education initiatives to prevent mosquito bites [7] and rapidly deployable vector control programs, such as aerial spraying [8], public funding for these programs is frequently 
strained, delays are not uncommon, and mosquitoes are becoming increasingly resistant to insecticides. These realities suggest that the spread of mosquito-borne Zika in the US will continue to be an area of concern as hurricanes continue to threaten the Atlantic coast in the coming years [9].

However, Zika presents a unique, additional challenge to public health because of an often overlooked, alternative vector for disease transmission-men, transmitting the virus to women via sexual contact with their semen. Given the risk of unintended pregnancy compounded by the risk of congenital anomaly among pregnancies infected by Zika, all routes of infection need to be addressed. A comprehensive, enduring Zika prevention plan should not only address the control of mosquitoes, but also examine the role of male sexual partners in the spread of Zika. Recommending that men practice abstinence and use condoms is not enough. Men should be actively educated about the risks of Zika and engaged in prevention efforts that emphasize the need for men to take on greater reproductive responsibility, as well as provide options for them to do so-comprehensive sex education, couples-inclusive contraceptive and abortion counseling, vasectomy, and the eventual development of novel male contraceptives.

\section{Main text}

In 2016, the Center for Disease Control and Prevention (CDC) reported on the first case of asymptomatic male-to-female transmission of Zika in the US [10]. Sufficient evidence was accumulated in the same year linking severe neurodevelopmental anomalies, such as microcephaly, to the transmission of Zika from mother to fetus. Notably, a review of the CDC-sponsored US Zika Pregnancy Registry found that among 85 pregnancies with Zika exposure during the first trimester, 9 (11, 95\%CI: 6-19\%) exhibited neurodevelopmental defects [11]. These findings led the World Health Organization (WHO) to designate Zika as a Public Health Emergency of International Concern and issue a strategic response plan [12], specifically identifying the sexual partners of reproductive-age women as a target for education about the risk of and methods to prevent Zika transmission. As Zika can be detected in the semen for as many as 188 days, the WHO recommends that sexual partners traveling in and returning from Zika-infected areas (e.g., Brazil, Costa Rica, Cuba, Peru, Puerto Rico, etc.) should use condoms or abstain from sexual activity and avoid conceiving for no fewer than 6 months to avoid potentially transmitting Zika to sexual partners and/or pregnancies [13].

Adhering to recommendations to consistently use condoms or remain abstinent for 6 months, however, may be challenging for men, as well as for couples who do not or cannot use female methods of contraception.
Further, the recommendation to start using condoms or adopt abstinence may not be realistic among couples in long-term or committed relationships. For adult couples who adopt condoms, the loss of sexual pleasure is reported by both men and women [14]. Further, a prospective study of couples using condoms over 4 weeks cited condom breakage or slippage among nearly $8 \%$ of couples [15], thereby raising doubts about the ability of couples to maintain perfect use of condoms. Consequently, among couples who use condoms to prevent pregnancy, $13 \%$ will typically experience an unintended pregnancy over the course of 1 year [16]. Regardless of whether this proportion is attributed to contraceptive failure or noncompliance, it highlights the incompleteness of recommendations for couples to rely solely on condoms to avoid pregnancy.

From a disease prevention standpoint, a survey of 520 Brazilian women noted that while nearly all women knew that Zika could be transmitted vertically, only $10.6 \%$ of pregnant women were using condoms to prevent sexual transmission [17]. While no study has examined rates of successful abstinence and condom use among couples following a possible Zika exposure, prospective research among sexually active, heterosexual, HIV-serodiscordant couples notes significant decreases in rates of abstinence and increases in rates of unprotected intercourse after 6 months of follow-up [18]. These findings suggest that "safe sex" messages may not be effective in preventing the spread of even a lethal sexually transmitted disease with known maternal-to-child transmission. As unsafe sex was more likely to occur in this study among couples where women were younger or less educated, disease transmission may be related to differences in power and reproductive agency or ineffective communication between women and their male partners. In some studies, women who report having contracted a sexually transmitted infection in the past continue to endorse difficulty with negotiating the use of condoms with their male sexual partners [19]. These concerns were supported in focus groups conducted among Brazilian women who claimed that men were either not aware of or concerned about the Zika risk, and that men would only use condoms if the women specifically demanded [20]. Given these findings, rather than relying solely on recommendations to use condoms or abstain, disease prevention may require a deeper understanding of men's sexual and reproductive responsibility and relationship dynamics, as well as education and counseling initiatives to sensitize them to the risk that their behaviors, or lack of behaviors, pose to women.

Engaging men in the responsibility to abstain or use contraception is a gender equity issue, as women cannot bear the sole burden of preventing a pregnancy that could otherwise lead to a Zika-affected infant, particularly when the male partner in a relationship may very 
well be invested in the well-being of their child. The potential consequences of not sensitizing men to the need for contraception, with respect to the spread of Zika, are illustrated by the gender gap in women's political empowerment in Brazil, which has widened over the past decade [21], leaving a political male majority, unaware of the value and need for access to both contraception and abortion. In Brazil, neither the levonorgestrel intrauterine system nor the subdermal contraceptive implant are subsidized by the government. A proposal to include these methods in the national health system was rejected by the Brazilian Ministry of Health on the grounds of high cost [22]. Additionally, the spread of Zika in Brazil and advisories about its linkage to microcephaly among infected infants led to a more than $100 \%$ increase in requests for abortions from Women on Web, an organization providing access to medical abortion in countries where abortion is not universally available or where abortion is illegal [23]. During this time, the Brazilian government was confiscating shipments of pills to be used for medical abortion and considered increasing the severity of sentences for women trying to obtain abortions to prevent the birth of infants with Zika-related anomalies [24], possibly contributing to nearly five thousand cases of microcephaly reported in Brazil from mid-2015 to early 2016 [25]. For men in political power in Brazil to restrict access to both contraception and abortion highlights their lack of both reproductive awareness and accountability. The case of Brazil provides a cautionary tale for legislators in other regions, such as Texas, where sexually-transmitted cases of Zika have been reported [26], and where funding for family planning services have been severely cut and numerous restrictions imposed on abortion [27]. As $80 \%$ of US congress members are men and as the Trump administration continues to threaten the provision of contraception by institutions such as Planned Parenthood [28], their awareness of the importance of family planning and its relevance to men is particularly important.

For men who recognize their role as vectors in the spread of Zika-related fetal anomalies, the shortcomings of barrier and female-controlled contraceptive methods may prompt them to consider their own options. For couples who no longer desire child-bearing, vasectomy may be considered. However, access to vasectomy in the US is limited by provider shortages in rural areas. Additionally, while US legislation via the Affordable Care Act mandates that health insurance providers cover essential preventative services such as female sterilization, vasectomy is explicitly excluded from the mandate, leaving logistic and surgical burdens on women [29].

The limits of men's family planning services should prompt greater demand for new methods of male contraception. To date, contraceptive development has disproportionately focused on methods for women, with attempts to develop new male contraceptives largely abandoned by pharmaceutical companies due to concerns about side effects and the perceived lack of demand among men. In fact, Family Planning 2020, the global campaign committing numerous governments and foundations to ensuring women's access to contraception and family planning, makes no mention of broadening contraceptive access for men [30], despite active conduct of human clinical trials on hormonal male contraceptive pills, injectables, implants, and topical gels [31], as well as research on multi-purpose contraceptives or spermicides with anti-viral activity [32]. The enduring oversight of men's attention to family planning and their reproductive responsibility at both levels of industry and policy, contrasts enduring evidence from surveys of men. For example, an international survey of more than 9000 men in 2002 found willingness to use a novel method of male contraception among $50-83 \%$ of respondents [33]. Additionally, while the most recent international efficacy trial of a male hormonal contraceptive injection combining 200-mg of norethisterone enanthate combined with 1000-mg testosterone undecanoate was stopped early due to concerns related to the frequency of reported mood-related side effects, more than $80 \%$ of male participants endorsed their willingness to use this method of male contraception in the future [34]. In 2018, another international trial of a male hormonal contraceptive gel will begin [35], aimed at providing men with an easily applicable method with which they may be able to prevent an unintended pregnancy. Other non-hormonal methods of male contraception are also being studied, such as injections to reversibly occlude the vas deferens and drugs to interrupt the development or motility of sperm [36]. Their success will be dependent upon men's recognition of the importance of their engagement in family planning. We hope that further efforts to improve men's engagement in family planning and their contraceptive options will precede further threats to the women and children whom men aim to protect at all levels.

\section{Conclusions}

While Zika is no longer a global emergency, the World Health Organization recognizes Zika as an enduring public health challenge. As neither an antiviral treatment nor a vaccine for Zika have emerged, prevention is the only viable strategy. The success of recommendations to prevent the spread of Zika both to women and their pregnancies however, is dependent upon the reproductive responsibility of and contraceptive access for both men and women. Recommendations for strict adherence to condoms or the maintenance of abstinence following Zika exposure and infection do not adequately recognize 
a reality for some women where abstinence may not be a choice, where the use of condoms cannot be negotiated with their male partner, or where their own contraceptives may be medically contraindicated. Effective strategies to mitigate the risk of Zika need to educate and engage men in their reproductive responsibility, educate them about the importance of contraception and abortion, as well as increase the range of contraceptives with which they can equally participate in prevention.

\section{Abbreviations}

CDC: Centers for Disease Control and Prevention; WHO: World Health Organization

\section{Authors' contributions}

BTN developed the concept for the manuscript. Both authors (BTN and RS) were involved in drafting of the manuscript and revising for important intellectual content, have given final approval of the manuscript for submission, and agree to be accountable for all aspects of the work. Both authors read and approved the final manuscript.

\section{Authors' information}

BTN is the assistant fellowship program director for the University of Southern California Fellowship in Family Planning and has a research focus in male contraception and male engagement in reproductive health. RS is currently a fellow in Family Planning at the University of Southern California.

\section{Ethics approval and consent to participate}

Not applicable.

\section{Consent for publication}

Not applicable.

\section{Competing interests}

The authors declare that they have no competing interests.

\section{Publisher's Note}

Springer Nature remains neutral with regard to jurisdictional claims in published maps and institutional affiliations.

Received: 23 February 2018 Accepted: 27 June 2018

Published online: 08 October 2018

\section{References}

1. Centers for Disease Control and Prevention. Zika Virus -2017 Case Counts in the US [Internet]. 2017 [cited 2018 Jan 2]. Available from: https://www. cdc.gov/zika/reporting/2017-case-counts.html

2. Vaccaro C. Extremely active 2017 Atlantic hurricane season finally ends/National Oceanic and Atmospheric Administration [Internet]. National Oceanic and Atmospheric Administration. 2017 [cited 2018 Jan 30]. Available from: http://www.noaa.gov/media-release/extremely-active-2017atlantic-hurricane-season-finally-ends

3. Geophysical Fluid Dynamics Laboratory. Global Warming and Hurricanes: An Overview of Current Research Results [Internet]. National Oceanic and Atmospheric Administration. 2018 [cited 2018 Jan 28]. Available from: https://www.gfdl.noaa.gov/global-warming-and-hurricanes/

4. Donner W, Rodriguez H. Population composition, migration and inequality: the influence of demographic changes on disaster risk and vulnerability. Soc Forces. 2008:87(2):1089-114. Available from: https://academic.oup.com/ sf/article-lookup/doi/10.1353/sof.0.0141

5. Ligon BL. Infectious diseases that pose specific challenges after natural disasters: a review. Semin Pediatr Infect Dis. 2006;17(1):36-45. Available from: http://www.ncbi.nlm.nih.gov/pubmed/16522504

6. Caillouët KA, Michaels SR, Xiong X, Foppa I, Wesson DM. Increase in West Nile neuroinvasive disease after hurricane Katrina. Emerg Infect Dis. 2008; 14(5):804-7. Available from: http://www.ncbi.nlm.nih.gov/pubmed/18439367

7. Clark GG, Hayes EB, Gubler DJ, Vorndam AV, O'Leary DR, Rigau-Pérez JG. Assessment of dengue risk in relief workers in Puerto Rico after hurricane
Georges, 1998. Am J Trop Med Hyg. 2002;66(1):35-9. Available from: http:/www.ajtmh.org/content/journals/10.4269/ajtmh.2002.66.35

8. Harris JW, Richards SL, Anderson A. Emergency mosquito control on a selected area in eastern North Carolina after hurricane irene. Environ Health Insights. 2014;8(Suppl 2):29-33. Available from: http://www.ncbi.nIm.nih.gov/ pubmed/25574141

9. Ahmed QA, Memish ZA. The public health planners' perfect storm: hurricane Matthew and Zika virus. Travel Med Infect Dis. 2017;15:63-6. Available from: http://www.sciencedirect.com/science/article/pii/ S1477893916302113

10. Brooks RB, Carlos MP, Myers RA, White MG, Bobo-Lenoci T, Aplan D, et al. Likely sexual transmission of Zika virus from a man with no symptoms of infection — Maryland, 2016. MMWR Morb Mortal Wkly Rep. 2016;65(34): 915-6. Available from: http://www.cdc.gov/mmwr/volumes/65/wr/ mm6534e2.htm

11. Honein MA, Dawson AL, Petersen EE, Jones AM, Lee EH, Yazdy MM, et al. Birth defects among fetuses and infants of US women with evidence of possible Zika virus infection during pregnancy. JAMA. 2017;317(1):59. Available from: http://jama.jamanetwork.com/article.aspx?doi=10.1001/jama. 2016.19006

12. WHO|Zika strategic response plan. WHO, 2016 [cited 2018 Jan 4]; Available from: http://www.who.int/emergencies/zika-virus/quarterly-update-october/en/

13. Gulland A. Men and women should practise safe sex for six months to avoid Zika, says WHO. BMJ. 2016;354:14897. Available from: http://www.ncbi. nlm.nih.gov/pubmed/27609128

14. Crosby R, Milhausen R, Yarber WL, Sanders SA, Graham CA. Condom 'turn offs' among adults: an exploratory study. Int J STD AIDS. 2008;19(9):590-4. Available from: http://journals.sagepub.com/doi/10.1258/ijsa.2008.008120

15. Trussel J, Warner L, Hatcher R. Condom slippage and breakage rates: comparison of the Pleasure Plus and Trojan-Enz condoms. [Internet]. [Unpublished] 1991 May 23.; 1991 [cited 2018 Feb 2]. Available from: https://www.popline.org/node/318467

16. Sundaram A, Vaughan B, Kost K, Bankole A, Finer L, Singh S, et al. Contraceptive failure in the United States: estimates from the 2006-2010 National Survey of family growth. Perspect Sex Reprod Health. 2017;49(1):7-16.

17. Borges ALV, Moreau C, Burke A, Dos Santos OA, Chofakian CB. Women's reproductive health knowledge, attitudes and practices in relation to the Zika virus outbreak in Northeast Brazil. PLoS One. 2018;13(1):e0190024. Available from: http://www.ncbi.nlm.nih.gov/pubmed/29298358

18. Skurnick JH, Abrams J, Kennedy CA, Valentine SN, Cordell JR. Maintenance of safe sex behavior by HIV-serodiscordant heterosexual couples. AIDS Educ Prev. 1998;10(6):493. Available from: https://www.ncbi.nlm.nih.gov/pubmed/ 9883285.

19. East $L$, Jackson D, O'Brien L, Peters K. Condom negotiation: experiences of sexually active young women. J Adv Nurs. 2011;67(1):77-85. Available from: http://doi.wiley.com/10.1111/j.1365-2648.2010.05451.x

20. Marteleto $\amalg$, Weitzman A, Coutinho RZ, Valongueiro Alves S. Women's reproductive intentions and behaviors during the Zika epidemic in Brazil. Popul Dev Rev. 2017;43(2):199-227. Available from: http://doi.wiley.com/10. 1111/padr.12074

21. The Global Gender Gap Report 2017 [Internet]. Geneva, Switzerland; 2017 [cited 2018 Feb 2]. Available from: https://www.weforum.org/reports/theglobal-gender-gap-report-2017

22. Brito M, Fraser I. Zika virus outbreak and the poor Brazilian family planning program. Rev Bras Ginecol Obstet. 2016;38(12):583-4. Available from: http:// www.thieme-connect.de/DOI/DOI?10.1055/s-0036-1593411

23. Aiken ARA, Scott JG, Gomperts R, Trussell J, Worrell M, Aiken CE. Requests for abortion in Latin America related to concern about Zika virus exposure. N Engl J Med. 2016;375(4):396-8. Available from: http://www.nejm.org/doi/ 10.1056/NEJMc1605389

24. Harris $\mathrm{LH}$, Silverman NS, Marshall MF. The paradigm of the paradox: women, pregnant women, and the unequal burdens of the Zika virus pandemic. Am J Bioeth. 2016;16(5):1-4. Available from: http://www.tandfonline.com/doi/ full/10.1080/15265161.2016.1177367

25. Victora CG, Schuler-Faccini L, Matijasevich A, Ribeiro E, Pessoa A, Barros FC. Microcephaly in Brazil: how to interpret reported numbers? Lancet. 2016; 387(10019):621-4. Available from: http://linkinghub.elsevier.com/retrieve/pii/ S0140673616002737

26. McCarthy M. Zika virus was transmitted by sexual contact in Texas, health officials report. BMJ. 2016;352:1720. Available from: http://www.ncbi.nlm.nih. gov/pubmed/26848011 
27. White K, Grossman D, Hopkins K, Potter JE. Cutting family planning in Texas. N Engl J Med. 2012;367(13):1179-81. Available from: http://www.nejm.org/ doi/abs/10.1056/NEJMp1207920

28. Grossman D. Sexual and reproductive health under the trump presidency: policy change threatens women in the USA and worldwide. J Fam Plan Reprod Heal care. 2017;43(2):89-91. Available from: http://www.ncbi.nlm.nih. gov/pubmed/28254782

29. Nguyen BTT, Shih G, DKK T. Putting the man in contraceptive mandate. Contraception. 2014;89(1):3-5.

30. Elias C, Kanem N. FP2020 the way ahead: 2016-2017 [Internet]. Family Planning 2020. 2017 [cited 2018 Feb 2]. Available from: http://progress. familyplanning2020.org/en

31. Wang C, Festin MP, Swerdloff RS. Male hormonal contraception: where are we now? Curr Obs Gynecol Rep. 2016;5:38-47.

32. Quaife $M$, Terris-Prestholt $F$, Vickerman $P$. The promise of multipurpose pregnancy, STI, and HIV prevention. Lancet Infect Dis. 2017;17(1):21-2. Available from: http://www.ncbi.nlm.nih.gov/pubmed/27998564

33. Heinemann K, Saad F, Wiesemes M, White S, Heinemann L. Attitudes toward male fertility control: results of a multinational survey on four continents. Hum Reprod [Internet]. 2005;20(2):549-56. Available from: http://humrep. oxfordjournals.org/content/20/2/549.abstract

34. Behre HM, Zitzmann M, Anderson RA, Handelsman DJ, Lestari SW, McLachlan $\mathrm{Rl}$, et al. Efficacy and safety of an injectable combination hormonal contraceptive for men. J Clin Endocrinol Metab. 2016;101(12):4779-88.

35. MacMillan A. Birth Control for Men? Researchers Will Test a Hormone Gel in 2018|Time [Internet]. Time. 2017 [cited 2018 Feb 2]. Available from: http://time.com/5077942/male-contraceptive-hormonal-gel/

36. Amory JK. Male contraception. Fertil Steril. 2016;106(6):1303-9.

\section{Ready to submit your research? Choose BMC and benefit from:}

- fast, convenient online submission

- thorough peer review by experienced researchers in your field

- rapid publication on acceptance

- support for research data, including large and complex data types

- gold Open Access which fosters wider collaboration and increased citations

- maximum visibility for your research: over $100 \mathrm{M}$ website views per year

At BMC, research is always in progress.

Learn more biomedcentral.com/submissions 